\title{
VALUATION OF FLEXIBLE LEASES FOR CORPORATE TENANTS FACING UNCERTAINTY IN THEIR REQUIRED WORKSPACE
}

\author{
Baabak ASHURI \\ Economics of the Sustainable Built Environment (ESBE) Lab, School of Building Construction, \\ Georgia Institute of Technology, 280 Ferst Drive, 1st Floor, Atlanta, GA 30332-0680, USA \\ E-mail: baabak.ashuri@coa.gatech.edu ; Phone: (404) 385-7608; Fax: (404) 894-1641 \\ Web: http://www.coa.gatech.edu/ESBE
}

Received 30 January 2009; accepted 22 January 2010

\begin{abstract}
A valuation approach is presented to price flexible leases with expansion, contraction, and/or cancelation options from the corporate tenant perspective. This model uses the real option valuation approach and determines the flexibility value or the option premium of a lease. This premium is the maximum amount of money that the tenant is willing to invest in incorporating a specific flexible feature in the leasing arrangement. Our model considers uncertainty in the rental market, as well as uncertainty about the firm's required workspace in an integrated valuation framework.
\end{abstract}

KEYWORDS: Real options analysis; Pricing flexible leases; Uncertainty about the required workspace; Dynamic uncertainty of leasing market; Financial risk analysis

\section{INTRODUCTION}

Uncertainty has become an increasingly important subject in workspace planning of modern enterprises. Strategic changes in business models and practices drive uncertainty about workspace planning. Enterprise-wide transformation initiatives such as mergers/acquisitions, downsizing/expansion, restructuring, decentralization, development of new organizational forms, and outsourcing happen more often these days and have significant impacts on an organization's workspace requirements (Ashuri and Roper, 2006; Ashuri and Rouse, 2004; Becker and Sims, 2000). The recent economic crisis that impacts several firms in the United States and across the world also acts as an enormous source of uncertainty in workspace planning. Firms must cut unnecessary expenses, shut down unprofitable operational divisions, and lay off extra workforce to survive. These changes have dramatic impacts on firms' required workspaces. Therefore, the current practice in workspace planning is conducted under a substantial amount of uncertainty, due to the unpredictability of the firm's workforce size, the timing, and the length of demand for employees and operational facilities in a particular market.

Several innovative workspace strategies have been developed and used by corporate real estate and facility management professionals to respond to unpredictable fluctuations in workspace demands of various firms. Alternative Officing (AO) has grown to be a widely used workspace strategy in many firms to

International Journal of Strategic Property Management

ISSN 1648-715X print / ISSN 1648-9179 online (C) 2010 Vilnius Gediminas Technical University

http://www.ijspm.vgtu.lt

DOI: $10.3846 /$ ijspm.2010.05 
satisfy dynamic workspace demands (Becker, 1999; Becker and Sims, 2000; Davenport and Pearlson, 1988; IFMA, 1995). Recent studies have shown that alternative workplace strategies are one of the most popular approaches to accommodate work in many organizations (Becker and Sims, 2000). Shared office spaces (the just-in-time office, hoteling, and the nonterritorial office) and telecommuting (home offices, satellite facilities, and working from everywhere like hotels, airports, etc.) are only some examples of innovative options for AO (Ashuri and Roper, 2006; Becker and Sims, 2000; Becker and Steele, 2000).

In addition, since the early 1990s, corporate real estate practice has been going through structural transformation to response to this ever-changing business environment. Lengths of Commercial leases have been shortened since tenants demand leases that best suit their particular occupancy needs (French et al., 2000). Standard 25-year institutional leases of 1980s are rarely agreed in the current corporate real estate market. Firms seek more flexible occupational terms in their leases, shorter lease lengths, the ability to expand and contract the space occupied, break clauses with exit options, upward/downward rent reviews, and incentive packages for tenants (Lizieri et al., 1997).

One of the most common strategies that influence the current workspace planning practices is to incorporate flexibility in corporate leases. Flexible features in leases work as appropriate strategies for corporate tenants to cope with workspace uncertainty in the volatile business environment of the 21 st century, i.e., a tenant agrees to pay a premium to a landlord to incorporate a specific flexibility in its lease. This flexibility is in the form of an embedded option in the lease that gives the tenant specified right but not the obligation to exercise the option when it is financially sound. For instance, this flexibility can be the option to terminate the lease before the lease ends without paying any penalty. Other forms of flexible leases can be found in situations in which the firm has the right to expand or contract the size of its workspace as identified in the original lease.

Although incorporating flexible features in leases has been pushed from the demand side of corporate real estate market to the supply side, the market is still reluctant to this change. The lack of suitable computational models for pricing flexibility in leases is indicated as one of the most important reasons that landlords or their agents have not widely implemented flexible terms in their leases (French et al., 2000). Corporate real estate market, however, cannot afford to ignore the importance of including flexible terms in leases, particularly since the negotiation power between two parties has been leaning towards tenants. Corporate tenants have several choices between new developments and existing buildings to accommodate their workspace requirements. The existence of flexibility in leases has become an important issue in tenants' decisionmaking processes and companies are willing to pay premiums to have suitable flexible terms in their leases to limit losses in downturn economic conditions and/or take advantage of upturn economic conditions.

Corporate tenants have also been cautious to consider flexible leases, primarily because of the difficulty in valuating these leases. Traditional valuation approaches that have been used for conventional fixed-term leases are not appropriate for pricing flexible leases. These methods do not properly capture the value of flexibility as an important part of the evaluation process in leases. In addition, traditional valuation approaches do not consider the volatility of the firm's workspace demand in the evaluation procedure of leases or do not properly address firms' responses to evolving market conditions.

An option valuation approach is presented to price flexible leases with expansion, contraction, and/or cancelation options from 
the corporate tenant perspective. This model uses the real option valuation approach and determines the flexibility value or the option premium, which is the maximum amount of money that the tenant is willing to invest in incorporating a specific flexible feature in the leasing arrangement. Our model considers uncertainty in the rental market, as well as uncertainty about the firm's needed workspace in an integrated valuation framework. Tenants' optimal decisions to exercise options are also incorporated in our valuation model. This paper is structured as follows. The research background is summarized in Section 2. The traditional valuation approach for fixed-term leases and its limitations to price flexibility in option-based leases are summarized. A binomial lattice model based on the risk-neutral valuation approach is presented to evaluate flexible leases with the help of a simple example in Section 3. A model is presented for corporate tenants to evaluate the flexibility value of leases with expansion, contraction, and/or cancelation options. Several sensitivity analyses are conducted to investigate how changes in the value of our model parameters impact option premiums of flexible leases. A general valuation framework is then developed in Section 4 to price flexibility in leases. Conclusions and future work are discussed in Section 5.

\section{RESEARCH BACKGROUND}

The valuation of fixed leases is typically conducted by Discounted Cash Flow (DCF) analysis. Suppose a tenant signs on a lease to fulfill its specific workspace requirement in following next $\mathrm{N}$ months. Also suppose that the firm commits to pay $\mathrm{C}_{1}, \mathrm{C}_{2}, \ldots, \mathrm{C}_{\mathrm{N}}$ as monthly rent at the beginning of the $1^{\text {st }}, 2^{\text {nd }}, \ldots, \mathrm{N}^{\text {th }}$ month, respectively, i.e., the firm's cash flow consists of $\mathrm{N}$ payments over the $\mathrm{N}$-month life cycle of this lease. The DCF of this lease is computed by discounting the above $\mathrm{N}$ cash outflows back to the current time. Since the lease cash flow consists of just $\mathrm{N}$ payments and no other positive cash inflow, the risk-free rate of return will be used for the DCF analysis (Mun, 2003). Suppose the monthly risk-free rate of return is $\mathrm{rf}$. This rate is assumed to be constant during the life cycle of the lease and compounded monthly. In the United States the risk-free rate of return is usually determined as the average rate of return on the U.S. Treasury Bills (Brealey and Myers, 2003). The DCF of this lease is calculated as

$$
\mathrm{DCF}=\sum_{\mathrm{i}=1}^{\mathrm{N}} \frac{\mathrm{C}_{\mathrm{i}}}{\left(1+\mathrm{r}_{\mathrm{f}}\right)^{\mathrm{i}-1}} .
$$

The DCF calculation is, however, based on the basic assumption that the tenant is certain about its future workspace needs and the monthly rental rate is predetermined in the leasing arrangement. Therefore, the cash outflows are assumed to be known with certainty at the time of signing the lease. These assumptions are so demanding that many firms do not feel comfortable using fixed leases since they are uncertain about their workspace requirements as well as the future rental market. Therefore, flexible leases have become attractive to corporate tenants. The valuation of flexible leases, however, cannot be conducted by the conventional DCF analysis due to its basic inadequacy in treating uncertainty and respective management decisions in a systematic fashion.

The DCF analysis approach excludes tenants from making decisions and capitalizing on emerging opportunities during the lease life cycle. These decisions are made in the real world by corporate tenants and change the original lease cash flow structure. For instance, a tenant may have an option to terminate its lease if it reveals that the firm does not require workspace or another leasing opportunity with the lower rate becomes available in the market. See Grenadier (1995) for a more detailed discussion on the limitations of the DCF analysis approach in valuing flexible leases. 
These limitations can be overcome by using a different perspective on valuation under uncertainty recognized as the real option theory. The term 'real option' was first introduced by Myers (1977). It referred to the application of financial option pricing in finance and banking, such as Black and Scholes (1973) formula, to the assessment of non-financial or "real" business decisions with strategic management flexibility like multi-staged investments. The real option methodology is an emerging stateof-the-art financial engineering paradigm that addresses managerial flexibility and strategic behaviors of decision-makers under dynamic uncertainty (Amram and Kulatilaka, 1999; Dixit and Pindyck, 1994; Smit and Trigeorgis, 2004). It also provides an analytical framework to evaluate management flexibility in decision making regarding whether and how to proceed with the business opportunity while it considers the dynamic uncertainty of the business underlying factors.

The field of real option analysis has gone through a massive transition from a topic of modest academic interest in 1980s and 90s to considerable, active academic and industry attention (Borison, 2005). The real option methodology has been applied in several different domains, such as technology assessment (Shishko et al., 2004), research and development (Bodner and Rouse, 2007), mining (Mayer and Kazakidis, 2007), manufacturing (Bengtsson, 2001), healthcare (de Neufville et al., 2008), construction management (Ford et al., 2002), infrastructure planning and highway systems (Chiara et al., 2007), retailing (Ashuri, 2008; Ashuri et al., 2008), architecture and design of building systems (Greden and Glicksman, 2005; Greden et al., 2006), urban redevelopments (Leung and Hui, 2005), etc.

Real option analysis has also been used in real estate, land, and property development. Hutchison and Schulz (2007), Greden and
Glicksman (2005), and Patel et al. (2005) have conducted a comprehensive literature review on the application of real option analysis in real estate, property, and development land valuation. Titman (1985) uses the real option theory to determine the optimal development and the price of land option. Capozza and $\mathrm{Li}$ (2002) develop a real option model to describe why the developer should wait to start with development when it is likely that values go up and costs go down in the future. Leung and Hui (2000; 2002) and Patel and Paxson (2001) show how real option models can be used as a convenient method to price several development potentials. Geltner et al. (1996) and Geltner (1989) conduct real option analysis for investigating the effect of land-use choice and explaining the common phenomenon of vacant urban land, respectively. In particular, Grenadier (1995) uses a real option approach to valuing leases from the corporate real estate landlord perspective. The term structure of lease rates is derived endogenously in his approach, i.e., equilibrium lease rates for leases with options to renew or cancel are determined in his model.

A variety of analytical procedures have been developed in independent disciplines of management science/decision analysis and finance for real option analysis (see Borison, 2005) for a comprehensive review of real option analysis methods). Our model is developed to evaluate flexible leases based on an integrated finance/decision analysis approach. A binomial lattice model based on the riskneutral valuation approach is developed for evaluating flexible leases under the dynamic uncertainty of the corporate rental rate in the market. Uncertainty about the firm's required workspace is treated exogenously in our decision tree analysis model. Our option valuation approach will be presented with a simple example that is going to be used throughout this paper. 


\section{A REAL OPTION APPROACH TO EVALUATE FLEXIBLE LEASES}

A simple example will be used to show how a firm can determine the value of a flexible lease in a dynamic corporate real estate market. This value is defined from the corporate tenant's perspective considering uncertainty in both firm's workspace demand and the rental rate in leasing market.

\subsection{Simple example}

Suppose a firm is expanding to a new market and is trying to decide about how to structure an appropriate lease to accommodate its evolving workspace demand in following two years. To keep things as simple as possible, suppose the firm needs to immediately open a branch in this market to start its operation for the strategic matter. Also, suppose the firm can instantly acquire its required workspace from the corporate leasing market. Workspace calculation conducted by the corporate real estate and facility management department shows that the initial workspace demand of this organization is ID $=10,000$ Square Feet (SF). However, the firm is not sure whether it is going to stay in this market for the entire two years. It will exit the market at the beginning of next year if business conditions are not as satisfactory as once expected. Suppose the firm estimates that there is a $20 \%$ chance that it leaves this new market at the beginning of next year. Therefore, it is preferable for the firm to have a flexible lease that allows cancelation after a year without any penalty.

The firm also faces another source of uncertainty from the leasing market. This uncertainty is about short-term variations of the rental rate in the leasing market. A binomial option pricing model (Hull, 2008; Luenberger, 1998) based on the standard risk-neutral valuation approach (Trigeorgis, 1996) is used to evaluate the flexible lease with the cancelation option under the uncertainty about the future corporate rental rate as summarized below.

\subsubsection{The binomial option pricing model based on the risk-neutral valuation approach}

Suppose the unit corporate rental rate is initially IR $=20 \$ / \mathrm{SF} /$ month. This is the constant rate that the firm can sign the two-year lease on and fulfill its workspace requirements in following years. Suppose this rate will remain constant under the fixed lease arrangement. The corporate rental market, however, is subject to uncertainty, which can be characterized by volatility. Suppose the annual volatility of the rental growth rate is $\sigma=10 \%$. Historical data about the rental rate in a particular leasing market and/or subject matter experts' opinions can be used as a source of information to estimate the values of this parameter.

In the flexible lease, the firm has the right but not the obligation to cancel its original lease at the beginning of the next year when it is revealed that it does not require space or the rate in the rental market becomes lower than IR=20 $\$ / \mathrm{SF} / \mathrm{month}$. This option is valued based on the risk-neutral pricing approach whose key concept is that an option can be priced based on the construction of a portfolio of a specific number of shares of an underlying asset, and that can borrow against the shares at the risk-free rate to replicate the return of the option in a risk-neutral world (Copeland and Antikarov, 2001; Trigeorgis, 1996). A binomial lattice model, which has been developed for facilitating risk-neutral option pricing, is used to evaluate the flexible lease as summarized below.

To define a binomial option pricing lattice for the flexible lease, a basic period length of one month is considered, i.e., $\Delta \mathrm{t}=1$ month $=1 / 12$ year. According to the model, the current unit corporate rental rate is known, i.e., IR= $20 \$ / \mathrm{SF} /$ month. The rental rate at the beginning of the next month is one of only two possible values, which are defined to be multiples of the rental rate at the previous period - a multiple $\mathrm{u}$ for up and a multiple $\mathrm{d}$ for down where both $\mathrm{u}$ and $\mathrm{d}$ are positive with $\mathrm{u}>1$ and $\mathrm{d}<1$. In the 
risk-neutral valuation approach, the probabilities of the up and down movements - denoted by $p$ and $1-p$, respectively - are determined endogenously, directly derived from the ratio of up and down movement given a fixed risk-free interest rate $\mathrm{r}_{\mathrm{f}}$. Suppose the risk-free discount rate is $1 \% /$ month compounded monthly, i.e., $\mathrm{r}_{\mathrm{f}}=1 \%$ /month. Eq. 1 (Hull, 2008; Luenberger, 1998) summarizes the formulas for computing the parameters of the binomial lattice in the risk-neutral valuation approach:

$$
\left\{\begin{array}{l}
u=e^{\sigma \sqrt{\Delta t}} \\
d=e^{-\sigma \sqrt{\Delta t}} \\
p=\frac{1+r_{f}-d}{u-d}
\end{array}\right.
$$

where: $u>1+r_{f}>d$ to avoid any arbitrage opportunities and ensure $0<p<1$.

After substituting $\mathrm{r}_{\mathrm{f}}=1 \% /$ month, $\sigma=10 \% /$ year, and $\Delta \mathrm{t}=1 / 12$ year in Eq. 1, we will have $\mathrm{u}=1.03, \mathrm{~d}=0.97$, and $\mathrm{p}=0.67$. These values are used in Figure 1 to construct the binomial lattice model for evaluating the flexible lease using the risk-neutral valuation approach. Figure 1 shows the risk-neutral binomial lattice of the rental rate in the market. The initial unit corporate rental rate is $\mathrm{IR}=20 \$ / \mathrm{SF} / \mathrm{month}$. The rental rate at the beginning of the next month will be either $u \times I R$ with probability $p$ or $d \times I R$ with probability $1-p$. This variation pattern continues on for several months until the end of the year. The risk-neutral probability of moving upward from any node in this lattice is $\mathrm{p}$ and the risk-neutral probability of moving downward from any node is $1-p$. An upward movement followed by a down is identical to a down followed by an up in the binomial lattice. A lattice model is a simple, yet powerful, model to capture the continuous dynamic uncertainty of the rental market in an approximate discrete fashion. The lattice method has the good approximation feature of continuous time dynamics if the approximation time step is infinitesimal the distribution of the successive market rent ratio approaches to the lognormal distribution, which is consistent with the continuous time asset price based on the model setup (Hull, 2008; Luenberger, 1998).

Figure 1 also shows the probability mass function (possible values and respective probabilities) of the corporate rental rate at the beginning of next year under the risk-neutral valuation approach. Considering the binomial lattice formulation, the rental rate at the beginning of next year is a random variable that follows a discrete binomial distribution. There are several up and down movements required to reach a leaf node in this lattice from the root. Take any leaf node in month $\mathrm{n}=1,2,3$, $\ldots, 12$. This leaf node can be reached from the root node by $0 \leq \mathrm{k} \leq \mathrm{n}$ upside and $0 \leq \mathrm{n}-\mathrm{k} \leq \mathrm{n}$ downside movements across the lattice. The rental rate at the leaf node, then, becomes IR $\times \mathrm{u}^{\mathrm{k}} \mathrm{d}^{\mathrm{n}-\mathrm{k}}$, which has the following binomial distribution:

Prob (Rental Rate at the beginning of the

$$
\begin{aligned}
& \left.\mathrm{n}^{\text {th }} \text { month }=\mathrm{IR} \times \mathrm{u}^{\mathrm{k}} \mathrm{d}^{\mathrm{n}-\mathrm{k}}\right)= \\
& \left(\begin{array}{c}
\mathrm{n} \\
\mathrm{k}
\end{array}\right) \mathrm{p}^{\mathrm{k}}(1-\mathrm{p})^{\mathrm{n}-\mathrm{k}}
\end{aligned}
$$

For instance, after 10 upside and 2 down movements, which is $\mathrm{k}=10$ and $\mathrm{n}-\mathrm{k}=2$, the rental rate at the beginning of the next year will increase to $\mathrm{IR} \times \mathrm{u}^{\mathrm{k}} \mathrm{d}^{\mathrm{n}-\mathrm{k}}=20(1.03)^{10}(0.97)^{2}=$ $25.20 \$ / \mathrm{SF} / \mathrm{month}$. The risk-neutral probability of the event that the rental rate in the leasing market at the beginning of next year will become $25.20 \$ / \mathrm{SF} / \mathrm{month}$ is, therefore,

$$
\left(\begin{array}{l}
\mathrm{n} \\
\mathrm{k}
\end{array}\right) \mathrm{p}^{\mathrm{k}}(1-\mathrm{p})^{\mathrm{n}-\mathrm{k}}=\left(\begin{array}{c}
12 \\
10
\end{array}\right)(0.67)^{10}(0.33)^{2}=0.1264 \text {. }
$$

Similarly, all possible rental rates and respective risk-neutral probabilities at the beginning of the first year are computed in Figure 1. These values form the basis for the firm to make decisions about whether to continue the lease for another year. At the beginning of next year, the firm will continue the original lease for one more year if it requires space and the 


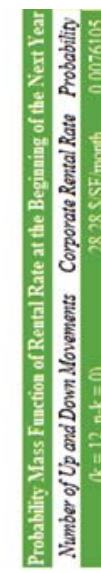

言

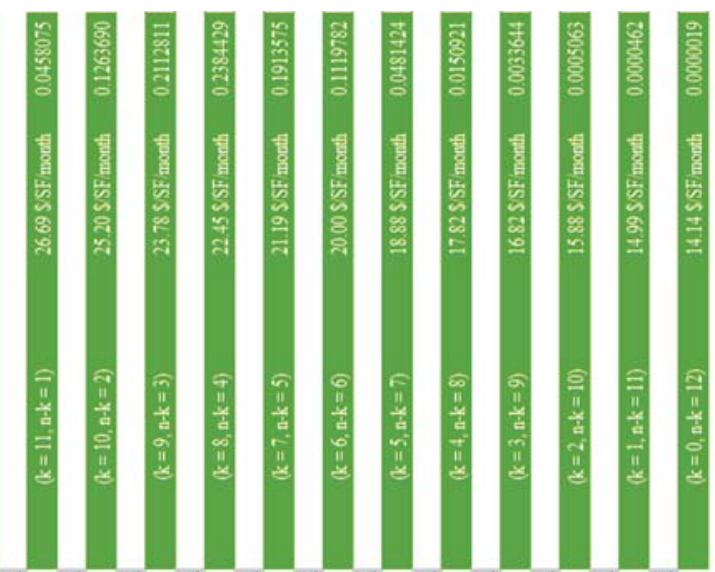

.

휳

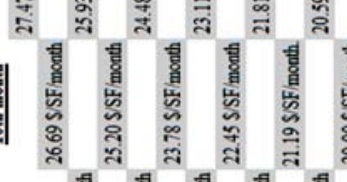

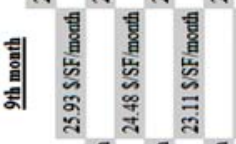

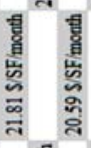

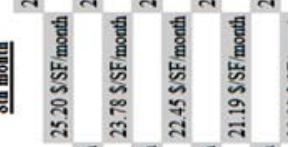

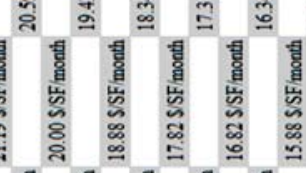

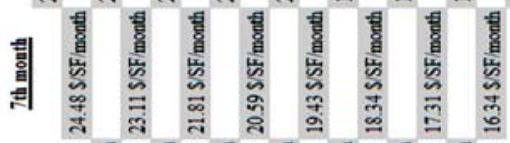

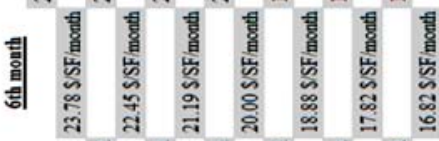

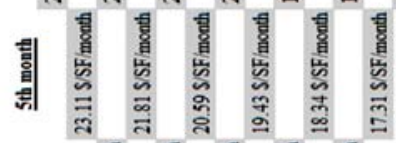

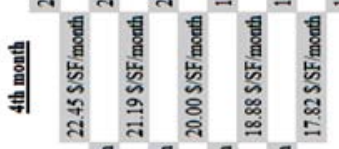

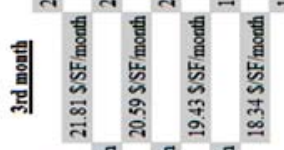

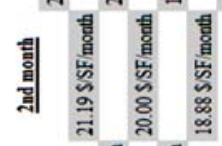

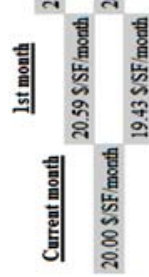


current leasing market rental rate is greater than the original rental rate, which is $20 \$ /$ $\mathrm{SF} / \mathrm{month}$ in this example. On the other hand, the firm terminates its lease when the current leasing market rental rate is lower than the originally agreed rate, which is $20 \$ / \mathrm{SF} /$ month. A summary of the firm's decision regarding whether to continue the original lease is provided in Figure 2. The firm's decision is based on the assumption that the firm can instantly find its required workspace in the rental market and immediately relocate to the new place without any extra cost.

The firm is interested in the described flexible lease since it gives the tenant right to cancel the original lease at the beginning of next year. This cancelation option, however, is not free. The firm is required to pay additional fee to incorporate this cancelation option and change the fixed traditional lease into this form of flexible lease. The firm is willing to pay this additional fee and chooses the flexible lease instead of the fixed lease if the firm expects to save more than this fee by acquiring the flexible lease. The value of cancellation option in the flexible lease is the firm's expected cost saving by choosing the flexible lease over the fixed lease. This value is, in fact, the option premium of the flexible lease with the cancelation right. The option premium is the difference between the DCFs of flexible and fixed leases. DCF calculation is summarized below.

\subsubsection{The DCF calculation for fixed and flexible leases}

DCF analysis will be conducted to compare the fixed and flexible leases. The fixed lease is a two-year contract and the flexible lease is a two-year contract with a renewal and cancelation right at the beginning of the next year. The traditional DCF analysis can be used to determine the expected cost of the fixed lease. This calculation is deterministic since the firm is committed to pay the fixed rental rate of $20 \$ / \mathrm{SF} / \mathrm{month}$ for next three years in the nonflexible lease arrangement. Suppose the firm pays the monthly rent at the beginning of each month. Future rental payments are discounted back to the present at the risk-free rate of return to compute the DCF of the fixed lease. Risk-free rate of return is the discount rate that should be used for valuation since the firm just experiences cash outflows or costs (Mun, 2003) in leases. Suppose the riskfree discount rate is $1 \% /$ month compounded monthly, i.e., $r_{f}=1 \% /$ month. The DCF of the firms' nonflexible lease - denoted by $\mathrm{DCF}_{\text {Non- }}$ flexible Lease - is computed, as follows.

$$
\begin{aligned}
& \mathrm{DCF}_{\text {Nonflexible Lease }}=\sum_{\mathrm{i}=0}^{23}[(20 \$ / \mathrm{SF} / \text { month } \times \\
& \left.10,000 \mathrm{SF} / \text { month }) \times\left(\frac{1}{1+0.01}\right)^{\mathrm{i}}\right]=
\end{aligned}
$$$$
\$ 4,291,164 \text {. }
$$

The DCF calculation of the flexible lease must be conducted under uncertainty about the firm's decision at the beginning of next year, as summarized in Figure 2. The binomial option pricing modeled, which is developed based on the risk-neutral probabilities, will be used in the flexible lease valuation. Therefore, the future cash outflows of the flexible lease will be discounted at the risk-free rate. The calculation of the expected DCF of the flexible lease - denoted by $\mathrm{E}\left(\mathrm{DCF}_{\text {Flexible Lease }}\right)$ - is computed as:

$$
\begin{aligned}
& \mathrm{E}\left(\mathrm{DCF}_{\text {Flexible Lease }}\right)= \\
& \mathrm{DCF}_{\text {The First-year Fixed Lease }}+\left(\frac{1}{1+0.01}\right)^{12} \times \\
& {\left[\mathrm { E } \left(\mathrm{DCF}_{\text {The Sec ond-year Flexible Lease }}\right.\right.} \\
& \text { at the Beginning of the NextYear })] .
\end{aligned}
$$

The first part of the flexible lease is the first-year fixed lease, which is fixed and identical to the fixed lease. This fixed part consists of twelve monthly payments of $20 \$ / \mathrm{SF} /$ month for the originally agreed of $10,000 \mathrm{SF}$ required 
space. The DCF of these fixed cash outflows is denoted by $\mathrm{DCF}_{\text {The First-year Fixed Lease }}$ and computed, as follows.

$$
\begin{aligned}
& \mathrm{DCF}_{\text {The First-year Fixed Lease }}= \\
& \sum_{\mathrm{i}=0}^{11}[(20 \$ / \mathrm{SF} / \text { month } \times \\
& \left.10,000 \mathrm{SF} / \text { month }) \times\left(\frac{1}{1+0.01}\right)^{\mathrm{i}}\right]=
\end{aligned}
$$$$
\$ 2,273,526 \text {. }
$$

The DCF calculation of the second-year flexible lease in the following year must be conducted considering uncertainty about the rental rate in the leasing market and whether the firm needs space. The expected DCF of the second-year flexible will be calculated based on the risk-neutral probabilities that are summarized in the probability mass function in Figure 1 . In addition, the chance that the firm does not require space in the following year should also be considered in this expected DCF calculation.

With probability $1-\mathrm{s}=0.2$, the firm does not need space and, therefore, the DCF of the flexible lease for the following year will be zero. With probability $\mathrm{s}=0.8$, the firm requires space and has the right to cancel the lease whenever the rental rate in the leasing market becomes lower than originally determined rental rate. The firm will cancel the original lease and change to the lease with the lower rate in the market when the rental rate at the beginning of next year becomes 18.88, 17.82, $16.82,15.88,14.99$, or $14.14 \$ / \mathrm{SF} /$ month. On the other hand, the firm will continue the original lease if the rental rate at the beginning of next year becomes 28.28, 26.69, 25.20, 23.78, $22.45,21.19$, or $20.00 \$ / \mathrm{SF} /$ month. The firm's optimal decisions, which are summarized in Figure 2, will be used to determine the firm's rental payments in following months. Figure 2 also summarizes the calculation procedure of the firm's DCFs for possible rental rates at the beginning of next year. For the rental rate of $28.28,26.69,25.20,23.78,22.45,21.19$, or $20.00 \$ / \mathrm{SF} / \mathrm{month}$, the firm's DCF at the beginning of next year - denoted by DCFFlexible Part - is calculated based on the rental rate of $20.00 \$ / \mathrm{SF} / \mathrm{month}$, as follows.

$$
\begin{aligned}
& \mathrm{DCF}_{\text {Flexible Part }}= \\
& \sum_{\mathrm{i}=0}^{11}[(20.00 \$ / \mathrm{SF} / \text { month } \times \\
& \left.10,000 \mathrm{SF} / \text { month }) \times\left(\frac{1}{1+0.01}\right)^{\mathrm{i}}\right]=
\end{aligned}
$$

$\$ 2,273,526$.

$\mathrm{DCF}_{\text {Flexible Part }}$ for other rental rates must be calculated with respect to the new rental rate in the leasing market. For instance, at the rental rate of $17.82 \$ / \mathrm{SF} /$ month $\mathrm{DCF}_{\text {Flexible Part }}$ is computed, as follows:

$$
\begin{aligned}
& \mathrm{DCF}_{\text {Flexible Part }}= \\
& \sum_{\mathrm{i}=0}^{11}[(17.82 \$ / \mathrm{SF} / \text { month } \times \\
& \left.10,000 \mathrm{SF} / \text { month }) \times\left(\frac{1}{1+0.01}\right)^{\mathrm{i}}\right]=
\end{aligned}
$$

$\$ 2,025,591$.

Considering the risk-neutral probability mass function of the rental rate at the beginning of next year, the expected DCF of the second-year flexible lease at the beginning of the next year in situations, for which the firm needs space, is calculated, as follows:

$$
\begin{aligned}
& \mathrm{E}\left(\mathrm{DCF}_{\text {The Sec ond-year Flexible Lease at the }}\right. \\
& \text { Beginning of the Next Year if the Firm Needs Space })= \\
& \sum_{\mathrm{j}=0}^{12}\left(\text { Pr obability }_{\mathrm{j}} \times \mathrm{DCF}_{\text {Flexible Part }_{\mathrm{j}}}\right)= \\
& \$ 2,262,162
\end{aligned}
$$

where: Probablity $\mathrm{j}_{\mathrm{j}}$ and $\mathrm{DCF}_{\text {Flexible Part }_{\mathrm{j}}} \mathrm{j}=0$, $1,2, \ldots, 12$ are the risk-neutral probability of the rental rate and the DCF of the flexible 


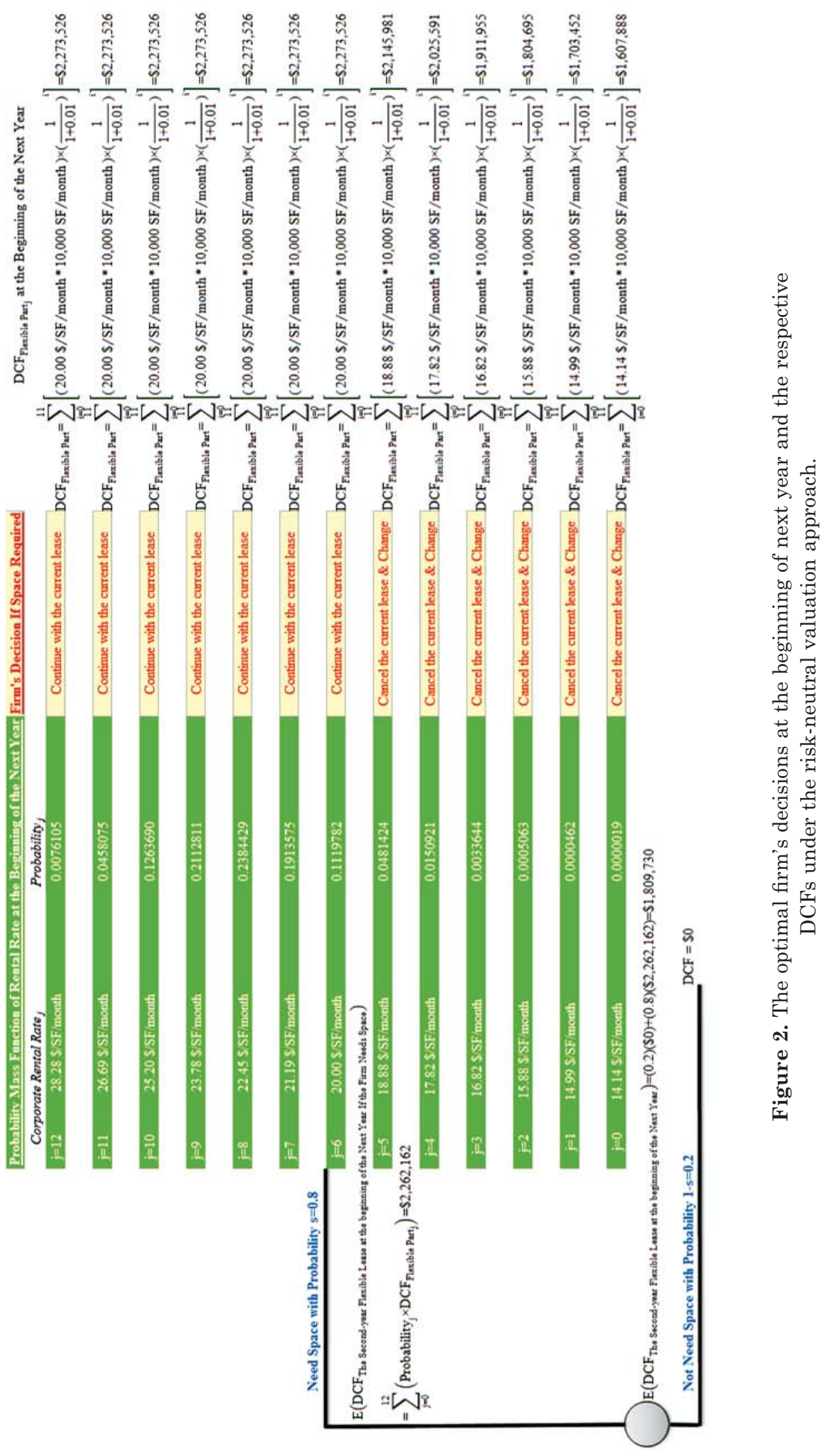


lease at the beginning of next year, respectively; $j=0$ corresponds to the possible rental rate of $20(1.03)^{0}(0.97)^{12}=14.14 \$ / \mathrm{SF} /$ month; $\mathrm{j}=1$ corresponds to the possible rental rate of $20(1.03)^{1}(0.97)^{11}=14.99 \$ / \mathrm{SF} /$ month; ...; $\mathrm{j}=12$ corresponds to the possible rental rate of $20(1.03)^{12}(0.97)^{0}=28.28 \$ / \mathrm{SF} / \mathrm{month}$ as shown in Figure 2.

Considering the uncertainty about whether the firm would need space in the following year, the expected DCF of the second-year flexible lease at the beginning of next year can be calculated, as follows:

$$
\begin{aligned}
& \mathrm{E}\left(\mathrm{DCF}_{\mathrm{The}} \mathrm{Sec}\right. \text { ond-year Flexible Lease at the } \\
& \text { Beginning of the Next Year })=(0.2) \\
& \left(\mathrm{DCF}_{\text {The Sec ond-year Flexible Lease at the Beginning }}\right.
\end{aligned}
$$$$
\text { of the Next Year If the Firm Does Not Space }))+(0.8)
$$$$
\text { ( } \mathrm{E}\left(\mathrm{DCF}_{\mathrm{The}} \mathrm{Sec}\right. \text { ond-year Flexible Lease at the Beginning }
$$$$
\text { of the Next Year If the Firm Needs Space }))=(0.2)
$$$$
(\$ 0)+(0.8)(\$ 2,262,162)=\$ 1,809,730 \text {. }
$$

This expected DCF of the second-year flexible lease is discounted back to the present time and added to the DCF of the first-year fixed lease calculated in Eq. 5. The summation is the expected DCF of the entire flexible lease under evolving rental rates in the market and uncertainty about the firm's workspace demand at the beginning of the next year as summarized below:

$$
\begin{aligned}
& \mathrm{E}\left(\mathrm{DCF}_{\text {Flexible Lease }}\right)= \\
& \mathrm{DCF}_{\text {The First-year Flexible Lease }}{ }^{+} \\
& \left(\frac{1}{1+0.01}\right)^{12}\left[\mathrm { E } \left(\mathrm{DCF}_{\text {The Sec ond-year }}\right.\right. \\
& \text { Flexible Lease at the Beginning of the Next Year })]= \\
& (\$ 2,273,526)+\left(\frac{1}{1+0.01}\right)^{12} \times \\
& (\$ 1,809,730)=\$ 3,879,569 .
\end{aligned}
$$

As predicted, the expected DCF of the flexible lease is lower than the DCF of the nonflexible lease. The amount of money that the firm is able to save by the flexible lease can be considered as the flexibility value or the option premium of the flexible lease with cancellation right at the beginning of next year.

Flexibility Value (or Option Premium) $=$

$$
\mathrm{DCF}_{\text {Nonflexible Lease }}-\mathrm{E}\left(\mathrm{DCF}_{\text {Flexible Lease }}\right)=
$$

$\$ 4,291,164-\$ 3,879,569=$

$\$ 411,595$.

This flexibility value or option premium is the maximum amount of money that the firm may be willing to pay to incorporate the described cancelation feature in the lease. The actual extra cost for the flexible lease will be decided through negotiation between the firm and the corporate real estate landlord. The firm, however, should not pay more than the computed flexibility value to acquire the cancelation option from the corporate landlord. A specific formulation for the flexibility value calculation in the demonstrated model can be developed as follows.

Flexibility Value (or Option Premium) =

$\mathrm{DCF}_{\text {Nonflexible Lease }}-\mathrm{E}\left(\mathrm{DCF}_{\text {Flexible Lease }}\right)=$ $\left[\mathrm{DCF}_{\text {The First-year Fixed Lease }}+\left(\frac{1}{1+\mathrm{r}_{\mathrm{f}}}\right)^{12} \times\right.$

$\mathrm{DCF}_{\text {The }} \mathrm{Sec}$ ond-year Fixed Lease at the Beginning of the Next Year ]-

$\left[\mathrm{DCF}_{\text {The First-year Fixed Lease }}+\left(\frac{1}{1+\mathrm{r}_{\mathrm{f}}}\right)^{12} \times\right.$

$\mathrm{E}\left(\mathrm{DCF}_{\text {The }} \mathrm{Sec}\right.$ ond-year Fixed Lease at the

Beginning of the Next Year) $)]=$

$\mathrm{ID} \times\left(\frac{1}{1+\mathrm{r}_{\mathrm{f}}}\right)^{12}\left[\left(\sum_{\mathrm{i}=0}^{11} \frac{\mathrm{IR}}{\left(1+\mathrm{r}_{\mathrm{f}}\right)^{\mathrm{i}}}\right)-\right.$

$\left.\left(s \times\left(\sum_{j=0}^{12} \sum_{i=0}^{11} \frac{q_{j} \times \min \left(I R, R_{j}\right)}{\left(1+r_{f}\right)^{i}}\right)+(1-s) \times \$ 0\right)\right]$ 
where: ID is the initial firm's required workspace in Square Feet (SF); $r_{f}$ is the monthly risk-free rate of return compounded monthly measured in \%/month; IR is the current unit corporate rental rate measured in $\$ / \mathrm{SF} / \mathrm{month}$; $\mathrm{s}$ is the probability of the event that the firm requires space at the beginning of the next year; $\mathrm{Rj}$ is the unit corporate rental rate at the beginning of the next year, which in the lattice formulation is: $R_{j}=I R \times u^{j} d^{12-j}, j=0,1,2, \ldots$, $12\}$, and $\mathrm{q}_{\mathrm{j}}$ is the respective risk-neutral probability of $R_{j}$, which in the lattice formulation is: $\mathrm{q}_{\mathrm{j}}=\left(\begin{array}{c}12 \\ \mathrm{j}\end{array}\right) \mathrm{p}^{\mathrm{j}}(1-\mathrm{p})^{12-\mathrm{j}}, \mathrm{j}=\{0,1,2, \ldots, 12\}$. In this formulation, $u$ and $d$ are the ratios of upward and downward movements in the binomial lattice model, respectively and $\mathrm{p}$ is the risk-neutral probability. These parameters are defined endogenously in the risk-neutral binomial lattice model based on the annual volatility of the rental growth rate $\sigma$ and the risk-free rate of return $r_{f}$, as described in Eq. 1. Eq. 12 can be simplified as:

Flexibility Value (or Option Premium) $=$

$$
\begin{aligned}
& \operatorname{ID} \times\left(\frac{1}{1+\mathrm{r}_{\mathrm{f}}}\right)^{12} \times[(\mathrm{s} \times \\
& \left.\left(\sum_{\mathrm{j}=0}^{5} \sum_{\mathrm{i}=0}^{11} \frac{\left(\begin{array}{c}
12 \\
\mathrm{j}
\end{array}\right) \mathrm{p}^{\mathrm{j}}(1-\mathrm{p})^{12-\mathrm{j}} \times\left(\mathrm{IR}-\mathrm{IR} \times \mathrm{u}^{\mathrm{j}} \mathrm{d}^{12-\mathrm{j}}\right)}{\left(1+\mathrm{r}_{\mathrm{f}}\right)^{\mathrm{i}}}\right)\right)+ \\
& \left.\left((1-\mathrm{s}) \times\left(\sum_{\mathrm{i}=0}^{11} \frac{\mathrm{IR}}{\left(1+\mathrm{r}_{\mathrm{f}}\right)^{\mathrm{i}}}\right)\right)\right]
\end{aligned}
$$

Considering the risk-neutral probabilities of the next-year's rental rate, there are several possible outcomes for the DCF of the flexible lease. The cumulative probability distribution of the DCF of the flexible lease can be constructed to show the likelihood of these various scenarios.

\subsubsection{The cumulative probability distribution of the DCF of the flexible lease}

The DCF of the fixed lease is certain and constant $\mathrm{DCF}_{\text {Fixed Lease }}=\$ 4,291,164$. However, the DCF of the flexible lease can take several values. The DCF of the flexible lease depends on the possible rent scenarios of the corporate rental market and whether the firm needs the space at the beginning of the next year. Table 1 summarizes the possible DCFs of the flexible lease and their respective probabilities corresponding to different levels of rent at the beginning of the next year.

Table 1. The probability distribution of the flexible lease DCF

\begin{tabular}{lll}
\hline $\begin{array}{l}\text { Rental rate at the } \\
\text { beginning of the } \\
\text { next year }\end{array}$ & $\begin{array}{l}\text { DCF of the } \\
\text { flexible lease }\end{array}$ & Probability \\
\hline $14.14 \$ / \mathrm{SF} /$ month & $\$ 3,415,061$ & 0.0000019 \\
$14.99 \$ / \mathrm{SF} /$ month & $\$ 3,482,907$ & 0.0000462 \\
$15.88 \$ / \mathrm{SF} /$ month & $\$ 3,554,786$ & 0.0005063 \\
$16.82 \$ / \mathrm{SF} /$ month & $\$ 3,630,937$ & 0.0033644 \\
$17.82 \$ / \mathrm{SF} /$ month & $\$ 3,711,613$ & 0.0150921 \\
$18.88 \$ / \mathrm{SF} /$ month & $\$ 3,797,085$ & 0.0481424 \\
$\geq 20 \$ / \mathrm{SF} / \mathrm{month}$ & $\$ 3,887,637$ & 0.9328467 \\
\hline
\end{tabular}

This probability distribution of the flexible lease DCF will, then, be used to determine the Cumulative Distribution Function (CDF) of the flexible lease DCF as summarized in Table 2.

Table 2. The CDF of the flexible lease DCF

\begin{tabular}{cc}
\hline The DCF of the Flexible Lease & CDF \\
\hline $\mathrm{x}<\$ 3,415,061$ & 0 \\
$\$ 3,415,061 \leq \mathrm{x}<\$ 3,482,907$ & 0.0000019 \\
$\$ 3,482,907 \leq \mathrm{x}<\$ 3,554,786$ & 0.0000481 \\
$\$ 3,554,786 \leq \mathrm{x}<\$ 3,630,937$ & 0.0005544 \\
$\$ 3,630,937 \leq \mathrm{x}<\$ 3,711,613$ & 0.0039188 \\
$\$ 3,711,613 \leq \mathrm{x}<\$ 3,797,085$ & 0.0190108 \\
$\$ 3,797,085 \leq \mathrm{x}<\$ 3,887,637$ & 0.0671533 \\
$\mathrm{x} \geq \$ 3,887,637$ & 1 \\
\hline
\end{tabular}


The firm's decision maker or the tenant can observe the entire possible DCFs of the flexible lease and their respective likelihoods in Figure 3. This information is useful since the tenant understands the uncertainty about the flexible lease DCF considering the uncertainty in the corporate rental market. The tenant can also use this information and compare the flexible lease with the fixed lease. The CDF of the fixed lease DCF is shown along with the CDF of the flexible lease DCF in Figure 3. The CDF of the fixed lease DCF is consists of a single jump at $\$ 3,887,637$ since it is certain and constant. It is evident that the flexible lease dominates the fixed lease in all market conditions since the fixed lease DCF is greater than any possible DCFs of the flexible lease with the cancelation option. Risk profiles of the DCFs of the flexible and fixed leases shown in Figure 3 indicate that the flexible lease deterministically dominates the fixed lease since the DCF of the flexible under worst market conditions is lower than the DCF of the fixed lease, i.e., $\max \left(\mathrm{DCF}_{\text {Flexible Lease with the Cancelation Option }}\right)=$ $\$ 3,887,637<\mathrm{DCF}_{\text {Fixed Lease }}=\$ 4,291,164$.

Even in the simple flexible leasing arrangement, such as the one just described, there are many interesting questions that should be considered by the firm before deciding to pay any extra cost and engaging in the flexible lease. For instance, how would the firm's option premium change when the volatility of the rental growth rate increased or when uncertainty about whether the firm needs space in the

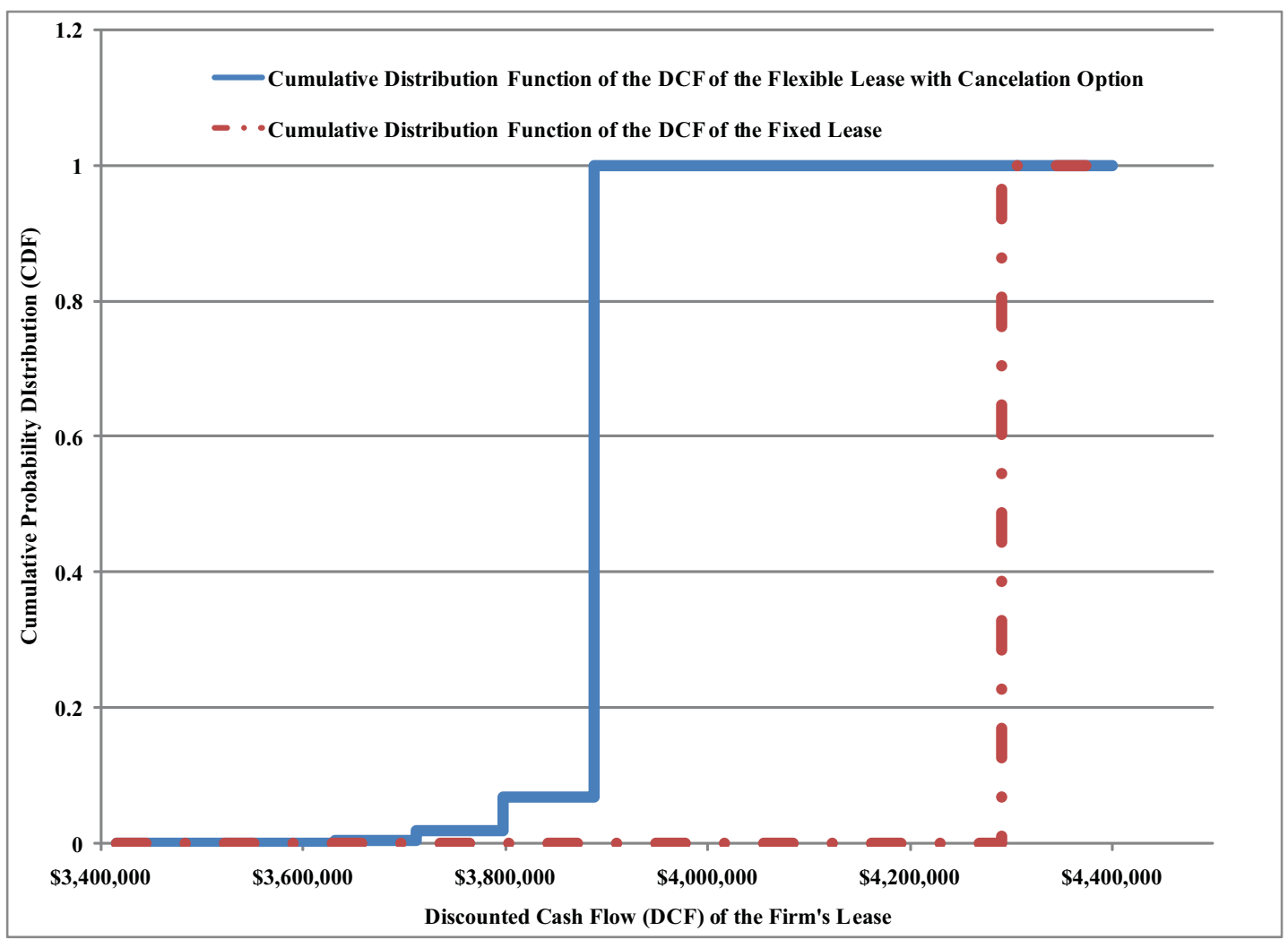

Figure 3. The Cumulative Distribution Function (CDF) of the Discounted Cash Flow (DCF) of the flexible and fixed leases. 
following year decreased? To answer these important questions, several sensitivity analyses will be conducted to study how changes in the model parameters impact the flexibility value of the lease with cancelation option.

\subsection{Sensitivity analysis}

Several sensitivity analyses are performed on parameters in our simple example. In each sensitivity analysis, the impact of changes in the value of a single variable on the firm's option premium in the flexible lease is investigated while the rest of model parameters remain constant at their original values.

The first sensitivity analysis is conducted to explore how changes in the probability of the event that the firm will require space for one-more year, i.e., parameter s in our model, impact the flexibility value or cancelation option premium. Figure 4 shows how the flexibility value or option premium decreases as this probability increases. As the probability of the event that the firm will require space for one-more year, increases the firm is more likely to continue the original lease. Thus, the cancelation option is not as attractive as situations in which the firm is more likely not to require workspace for one-more year. The flexible lease with the cancelation option is more attractive in situations where there is a higher degree of uncertainty about the future firm's required workspace. Therefore, the flexibility value of the lease with the cancelation option under high uncertainty about the need for future workspace is greater than the flexibility value under low uncertainty about the need for future workspace. This decreasing effect can be explained mathematically by revisiting Eq. 12 that describes the flexibility value formulation. The first derivative of the flexibility value function with respect to variable $l$ is negative, as shown below, which explains the decreasing effect in Figure 4.

$$
\begin{aligned}
& \frac{\partial(\text { Flexibility Value (or Option Pr emium }))}{\partial \mathrm{s}}= \\
& -\mathrm{ID} \times\left(\frac{1}{1+\mathrm{r}_{\mathrm{f}}}\right)^{12} \times \\
& \left(\sum_{\mathrm{j}=0}^{12} \sum_{\mathrm{i}=0}^{11} \frac{\mathrm{q}_{\mathrm{j}} \times \min \left(\mathrm{IR}, \mathrm{R}_{\mathrm{j}}\right)}{\left(1+\mathrm{r}_{\mathrm{f}}\right)^{\mathrm{i}}}\right)<0
\end{aligned}
$$

Figure 4 also shows that the flexibility value of cancelation option decreases linearly with respect to changes in the probability of the event that the firm will require space for one more year. This can also be explained mathematically by taking the second derivative of the flexibility option function with respect to variable $\mathrm{s}$. This second derivative is zero, as summarized below, which explains the linear shape of the graph in Figure 4.

$\frac{\left.\partial^{2}(\text { Flexibility Value (or Option Premium })\right)}{\partial \mathrm{s}^{2}}=0$

Figure 4 shows that the flexible lease with the cancelation option becomes less attractive to the tenant as it is more likely that the firm needs space for one more year. In these situations, the tenant may not be much concerned about the flexible lease.

The second sensitivity analysis is conducted to explore how changes in the annual volatility of the rental growth rate impact the flexibility value of the lease with cancelation option. The cancelation option is more-attractive for the firm as the rental market becomes morevolatile since it provides an opportunity for the firm to take advantage of the relatively lower rental rates as they become available in the market at the beginning of the next year. The tenant is highly interested in the flexible lease with the cancelation option as the uncertainty about the future rental market increases. The flexible lease is very attractive in the volatile rental market. 


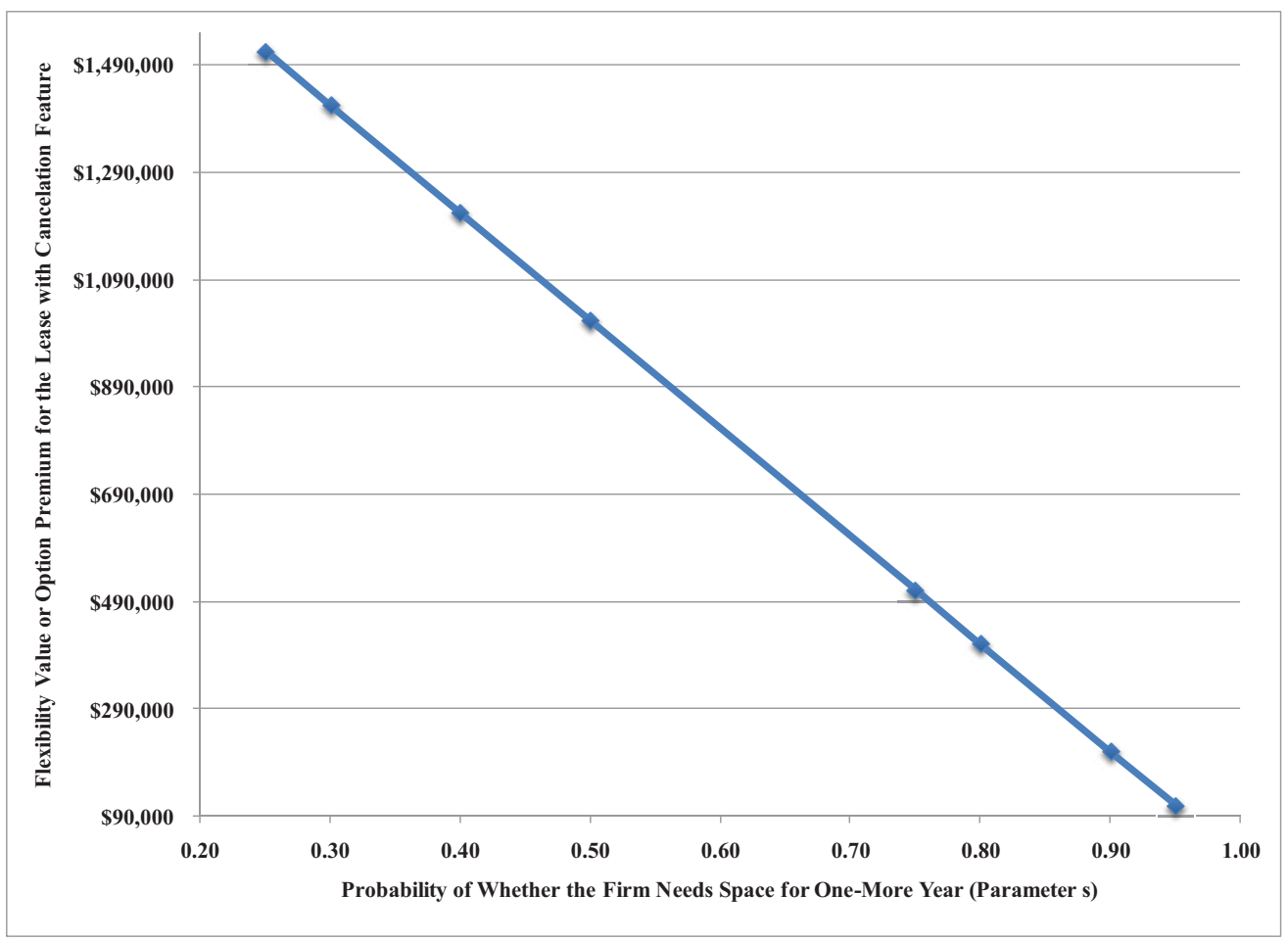

Figure 4. Impact of changes in the probability of the event that the firm needs space for one-more year (parameters) on the flexibility value.

Figure 5 shows how the flexibility value increases nonlinearly as the annual volatility of rental growth rate or parameter $\sigma$ increases. This nonlinear increasing trend can be explained by revisiting Eq. 1 through analysis of the impact of changes in parameter $\sigma$ on parameters $\mathrm{d}$ and $1-\mathrm{p}$. The downward movement ratio or parameter d in Eq. 1 decreases exponentially as parameter $\sigma$ increases. The tenant exercises the cancellation option when it needs space for another year and the market rental rate drops below the initial rental rate at the beginning of the next year. This is happened in the lattice formulation when the rental rate at the beginning of the next year takes one of the following values: $R_{j}=$ $I R \times \mathrm{u}^{\mathrm{j}} \mathrm{d}^{12-\mathrm{j}}=\mathrm{IR} \times(1 / \mathrm{d})^{\mathrm{j}} \mathrm{d}^{12-\mathrm{j}}=\mathrm{IR} \times \mathrm{d}^{12-2 \mathrm{j}} \mathrm{j}=$ $\{0,1,2, \ldots, 5\}$ where $12-2 \mathrm{j} \geq 0$. Hence, as $\mathrm{d}$ decreases exponentially the rental rate at the beginning of the next year in the above situations, in which the tenant cancels the original lease and switches to the lower rate lease, also decreases exponentially. In addition, it can be shown that the first derivate of $p$ with respect to $\sigma$ is negative, i.e., $p$ decreases or $1-p$ increases exponentially as $\sigma$ increases. The probabilities of the rental rate at the beginning of the next year in the above situations, in which the tenant cancels the original lease and switches to the lower rate lease, follow: $\left(\begin{array}{c}12 \\ j\end{array}\right) p^{j}(1-p)^{12-j}$, and $\mathrm{j}=\{0,1,2, \ldots, 5\}$. It can also be shown that that these probabilities increase exponentially as $1-p$ increases exponentially.

Therefore, the rental rate and the respective likelihood at the beginning of the next year in situations where the tenant may cancel the original lease and may switch to the lower rate lease, decreases and increases 


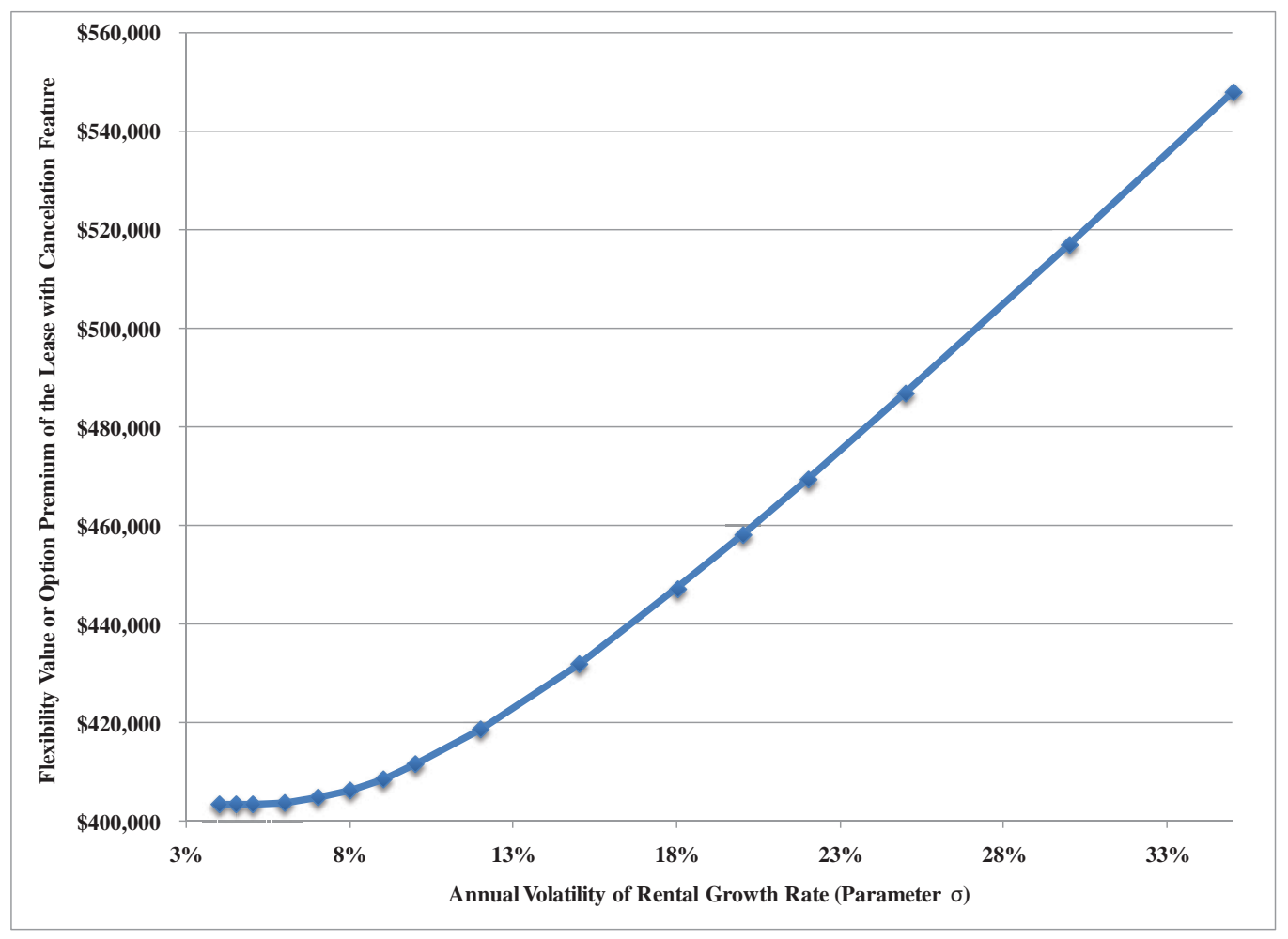

Figure 5. Impact of the annual volatility of rental growth rate (parameter $\sigma$ ) on the flexibility value.

exponentially, respectively. In combination, the expected value of the DCF of the flexible lease and consequently, its flexibility value increases exponentially.

The third sensitivity analysis is conducted to explore how changes in the monthly riskfree rate of return impact the flexibility value of the lease with cancelation option. Figure 6 shows how the flexibility value decreases nonlinearly as the monthly risk-free interest rate or parameter rf increases. The future cost savings of the flexible lease are discounted at rf to the present. As the discount rate increases the possible value of the cancelation option decreases. The tenant, then, becomes less interested in the future benefits of the flexible lease when the cost of money or risk-free rate of return is high. Therefore, the discounted future benefits of the flexible lease or the flexibility value decreases as the discount rate increases.

The nonlinear nature of this decreasing trend can be explained by revisiting Eq. 13, in which rf appears in the denominator of the function describing the option premium. In addition, according to Eq. 1 the increase in the value of parameter rf decreases the probability of downward movement or parameter $1-p$. The probabilities of the rental rate at the beginning of the next year in situations, in which the tenant cancels the original lease and switches to the lower rate lease, follow: $\left(\begin{array}{c}12 \\ j\end{array}\right) p^{j}(1-p)^{12-j}$, $\mathrm{j}=\{0,1,2, \ldots, 5\}$. It can also be shown that that these probabilities decrease exponentially as $1-p$ decreases exponentially. Therefore, it becomes less likely that the lower rent will be 


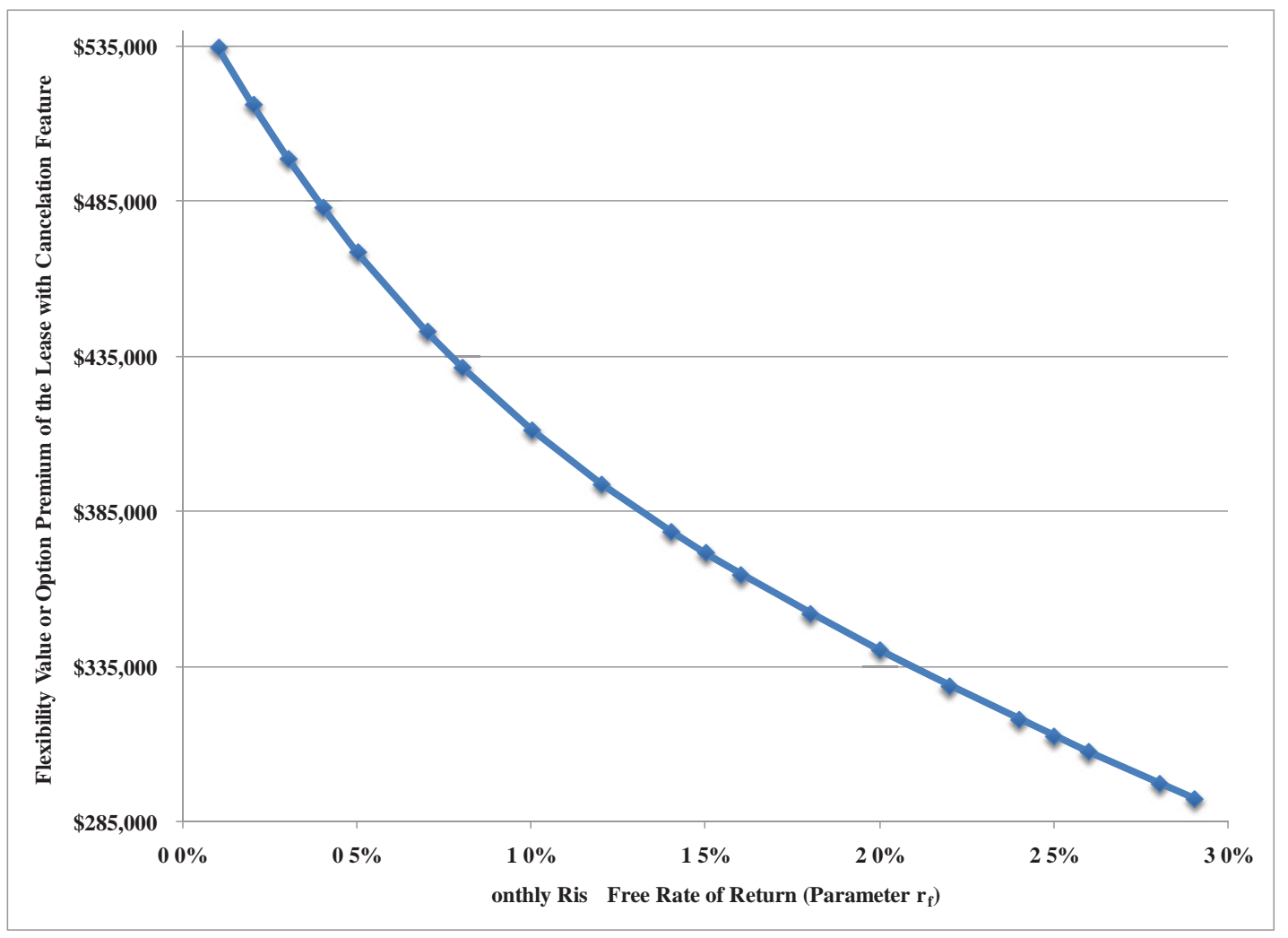

Figure 6. Impact of changes in the monthly risk-free rate of return (parameter $r_{f}$ ) on the flexibility value.

available in the market at the beginning of the next year. This also pushes down the option premium of the flexible lease.

\subsection{Valuation of flexible leases with additional expansion and contraction options}

The described framework can be used to determine flexibility values of leases that have expansion and contraction options, as well as cancelation options discussed before. Consider the same firm in our example that is planning to accommodate its required workspace in the following year. Currently, the firm's space demand is ID $=10,000 \mathrm{SF} /$ month. The firm is, however, uncertain about its future in this new market. Several scenarios may happen at the beginning of next year, as follows. The firm will require the same workspace size of 10,000 $\mathrm{SF} / \mathrm{month}$, expand its workspace size to 15,000 $\mathrm{SF} /$ month, contract its workspace to 5,000 SF/ month, or not need any space at all, with probabilities $\mathrm{s}_{1}=0.5, \mathrm{~s}_{2}=0.2, \mathrm{~s}_{3}=0.2$, and $\mathrm{s}_{4}=0.1$, respectively. Corresponding to these uncertain future scenarios, the firm is interested in incorporating appropriate flexible features in its lease to effectively manage workspace uncertainty, i.e., at the beginning of next year the firm wants to have options to keep, expand, contract, or cancel the original lease responding to the above scenarios, respectively.

The firm makes these decisions under evolving uncertainty in the rental market. The risk-neutral valuation approach is applied to assess this new flexible lease. The same binomial lattice framework, which is discussed 
in Section 3.1.1 and is shown in Figure 1, is used to evaluate this flexible lease with new options. In addition to the expansion and contraction options, the firm has the right to cancel the original lease at the beginning of the next year if it decides to exit the market or the lease with the relatively lower rental rate becomes available. The firm's expected DCF can be calculated using the risk-neutral probabilities of rental rates at the beginning of the next year as:

$\mathrm{E}\left(\mathrm{DCF}_{\text {Flexible Lease with Continuation, Cancelation, }}\right.$

Expansion, and Contraction Options) =

$\mathrm{DCF}_{\text {The First-year Fixed Lease }}+\left(\frac{1}{1+0.01}\right)^{12} \times$

$\left[\mathrm{E}\left(\mathrm{DCF}_{\mathrm{The}} \mathrm{Sec}\right.\right.$ ond-year Flexible Lease at the

Beginning of the Next Year)]

where: $\mathrm{DCF}_{\text {The First-year Fixed Lease }}=\$ 2,273,526$, which is identical to what was computed in Section 3.1.2 and

\section{$\mathrm{E}\left(\mathrm{DCF}_{\text {The Sec ond-year Flexible Lease at the }}\right.$}

Beginning of the Next Year) =

$\left(\mathrm{s}_{1} \times \mathrm{E}\left(\mathrm{DCF}_{\text {Require to Keep the Same Space }}\right)\right)+$

$\left(\mathrm{s}_{2} \times \mathrm{E}\left(\mathrm{DCF}_{\text {Require to Expand the Original Space }}\right)\right)+$

$\left(\mathrm{s}_{3} \times \mathrm{E}\left(\mathrm{DCF}_{\text {Require to Contract the Original Space }}\right)\right)+$

$\left(\mathrm{s}_{4} \times \mathrm{DCF}_{\text {Require No Space }}\right)$.

The calculation of $\mathrm{E}\left(\mathrm{DCF}_{\text {Require to Keep }}\right.$ the Same Space) is identical to what was described in Section 3.1.2 and, thus, is equal to $\$ 2,262,162$, as computed in Eq. 8. The calculation procedures for $\mathrm{E}\left(\mathrm{DCF}_{\text {Require to Expand }}\right.$ the Original Space $)$ and $\mathrm{E}\left(\mathrm{DCF}_{\text {Require to Contract the }}\right.$ Original Space) are also similar to what was described in our example in Section 3.1.2. The only thing that needs to be updated is the size of workspace required by the firm. 15,000 SF/ month and 5,000 SF/month must be used for expansion and contraction, respectively. Hence, we will have $\mathrm{E}\left(\mathrm{DCF}_{\text {Require to Expand the Original }}\right.$ Space $)=\$ 3,393,243$ and $\mathrm{E}\left(\mathrm{DCF}_{\text {Require to Contract }}\right.$ the Original Space $)=\$ 1,131,081$. It is evident that $\mathrm{DCF}_{\text {Require No Space }}=\$ 0$. We will then, have:

$\mathrm{E}\left(\mathrm{DCF}_{\text {The Sec ond-year Flexible Lease at the }}\right.$

Beginning of the Next Year $)=$

$(0.5 \times \$ 2,262,162)+(0.2 \times \$ 3,393,243)+$

$(0.2 \times \$ 1,131,081)+(0.1 \times \$ 0)=$

$\$ 2,035,946$.

Thus, the expected DCF of this flexible lease is:

$\mathrm{E}\left(\mathrm{DCF}_{\text {Flexible Lease with Continuation, Cancelation, }}\right.$

Expansion, and Contraction Options $)=$

$\$ 2,273,526+\left(\frac{1}{1+0.01}\right)^{12} \$ 2,035,946=$

$\$ 4,080,324$.

The expected DCF of this flexible lease must be compared with the expected DCF of the nonflexible lease to determine the flexibility value. If the lease was not flexible, the firm could not cancel its original lease at the beginning of next year when it does not require any space, wants to reduce the size of its workspace, or the lower rental rate becomes available in the market. Therefore, the firm must have paid $20 \$ / \mathrm{SF} /$ month for 10,000 $\mathrm{SF} / \mathrm{month}$ for two years regardless of how the firm's workspace demand would turn to be at the beginning of next year. In addition, the firm must lease extra 5,000 SF/month at the current market rate if its workspace demand turns to be $15,000 \mathrm{SF} /$ month at the beginning of next year. Thus, the expected DCF of the nonflexible lease consists of two parts: the fixed part or the DCF of the original two-year fixed lease of $10,000 \mathrm{SF} /$ month at the rate of $20 \$ / \mathrm{SF} / \mathrm{month}$; and the uncertain part or the 
expected DCF of one-more year lease of 5,000 $\mathrm{SF} / \mathrm{month}$ at the market rate at the beginning of the next year if the firm requires additional space. The expected DCF of the nonflexible lease is computed, as follows:

$$
\begin{aligned}
& \mathrm{E}\left(\mathrm{DCF}_{\text {Nonlexible Lease }}\right)= \\
& \mathrm{DCF}_{\text {The Original Two-year Fixed Lease }}{ }^{+} \\
& \left\{\mathrm{S}_{2} \times\left(\frac{1}{1+0.01}\right)^{12}\left[\mathrm { E } \left(\mathrm{DCF}_{\text {Additional Required }}\right.\right.\right. \\
& \text { Workspace at the Beginning of the Next Year })]\}
\end{aligned}
$$

where: $\mathrm{DCF}_{\text {The Original Two-year Fixed Lease }}=$ $\$ 4,291,164$ as computed in Eq. 3 of Section 3.1 .2 and $\mathrm{s}_{2}=0.2$, which is the probability of the event that the firm will require $15,000 \mathrm{SF} /$ month at the beginning of next year.

The calculation procedure for $\mathrm{E}\left(\mathrm{DCF}_{\text {Additional }}\right.$ Required Workspace at the Beginning of Next Year) is similar to what was described for our example in Eq. 8 of Section 3.1.2. The calculation, however, must be conducted for the required 5,000 $\mathrm{SF} / \mathrm{month}$ and based on risk-neutral probabilities of the rental rate at the beginning of next year, i.e., $\mathrm{E}\left(\mathrm{DCF}_{\text {Additional Required Workspace at the }}\right.$ Beginning of Next Lease $)=\$ 1,131,081$ and therefore, $\mathrm{E}\left(\mathrm{DCF}_{\text {Nonflexible Lease }}\right)=\$ 4,491,919$. It is evident that the flexible lease with continuation, cancelation, expansion, or contraction options is valuable for the firm in this uncertain market situation. The flexible value of the lease with continuation, cancelation, expansion, and contraction options is:

Flexibility Value $=\mathrm{E}\left(\mathrm{DCF}_{\text {Nonflexible Lease }}\right)-$ $\mathrm{E}\left(\mathrm{DCF}_{\text {Flexible Lease with Continuation, Cancelation, }}\right.$ Expansion, and Contraction Options $)=$

$\$ 4,491,919-\$ 4,080,324=$

$\$ 411,595$

\section{THE GENERAL VALUATION MODEL}

The computation procedure described in simple examples above can be readily extended to other forms of flexible leases that consider several options for the firm to revise its workspace arrangements during the length of its lease. A general procedure, which can be used to evaluate flexible leases with expand/ contract options for the firm under dynamic uncertainty about workspace requirements, is described below. This procedure is shown in Figure 7 and can be summarized in the following steps:

1. Determine input values for the following model parameters:

1.1. The entire length of a lease.

1.2. The total number of intermediate periods that the firm can adjust the lease (denoted by $\mathrm{k}$ in Figure 7) and the duration of intermediate leasing periods (denoted by $t_{1}, t_{2}, \ldots, t_{k}$ in Figure 7 ).

1.3. The initial amount of workspace required by the firm in the $1^{\text {st }}$ leasing period (denoted by ID in our described examples).

1.4. Probabilities of events that the firm will continue, expand, contract, or cancel the lease in any of the following intermediate leasing periods.

1.5. Estimated sizes of workspace (in square feet) required by the firm when it will expand or contract its current workspace in any of the following intermediate leasing periods.

1.6. The risk-free rate of return per month compounded monthly $r_{f}$, the annual volatility of the rental growth rate $\sigma$, and the basic period length of one month $\Delta \mathrm{t}=1$ month $=1 / 12$ year to compute the upward movement ratio $\mathrm{u}$, the downward movement ratio $d$, and the upward risk-neutral probability $\mathrm{p}$ according to Eq. 1 and build the binomial lattice model for the risk-neutral valuation of the flexible lease as shown in Figure 7). 
1.7. The risk-free rate of return per month compounded monthly rf is also used as a discount rate for the DCF calculation.

2. Calculate the expected DCF of the flexible lease:

2.1. For the initial (first) leasing period.

- Calculate cash flows according to the initial space required by the firm and the initial rental rate in the leasing market.

- Discount every cash flow at the rate rf to time $t_{0}$ and then add them up to compute the $1^{\text {st }}$ period DCF (denoted by $\mathrm{DCF}_{1}$ in Figure 7)

2.2. For the $2^{\text {nd }}$ intermediate leasing period.

- Calculate cash flows for continuation, expansion, contraction, and cancelation scenarios based on several possible rental rates in the leasing market at the beginning of the $2^{\text {nd }}$ period.

- For every possible cash flow, compute the DCF of continuation, expansion, contraction, and cancelation scenarios by discounting cash flows at the rate $r_{f}$ to time $t_{1}$.

- Considering the risk-neutral probabilities of rental rates at the beginning of the $2^{\text {nd }}$ period (specified in the binomial lattice of Figure 7), compute the expected $2^{\text {nd }}$ period DCF for continuation, expansion, contraction, and cancelation scenarios.

- Considering the probabilities of continuation, expansion, contraction, and cancelation scenarios in the $2^{\text {nd }}$ intermediate leasing period, compute the expected DCF of the flexible lease (denoted by $\mathrm{E}\left(\mathrm{DCF}_{2}\right)$ in Figure 7$)$.

2.3. Repeat step 2.2 for the $3^{\text {rd }}, 4^{\text {th }}, \ldots$, and $\mathrm{k}^{\text {th }}$ intermediate leasing periods and calculate the expected DCF of the flexible lease in these periods (denoted by $\mathrm{E}\left(\mathrm{DCF}_{3}\right), \mathrm{E}\left(\mathrm{DCF}_{4}\right), \ldots$, and $\mathrm{E}\left(\mathrm{DCF}_{\mathrm{k}}\right)$, respectively in Figure 7).

2.4. Discount intermediate leasing period DCFs to time $t_{0}$ and compute $\mathrm{E}(\mathrm{DCF})$ of the entire flexible lease, as summarized in Figure 7.
3. Calculate the expected DCF of the nonflexible lease:

3.1. Compute the deterministic DCF of the initial fixed lease based on the originally agreed rental rate and the firm's initial required workspace.

3.2. Considering the risk-neutral probabilities of the rental rate at the beginning of an intermediate leasing period, calculate the firm's expected DCF in case the firm requires additional workspace in the intermediate period.

3.3. Multiply the probability of expansion scenario by the firm's expected DCF of additional required workspace to compute the firm's expected DCF for possible expansion scenario in the intermediate leasing period.

3.4. Discount back the expected DCFs of additional required workspace in intermediate leasing periods to the present time to compute the whole expected DCF of the variable part of the nonflexible lease.

3.5. Sum fixed and variable DCFs to compute the expected DCF of the nonflexible lease.

4. Subtract the expected DCF of the flexible lease from the expected DCF of the nonflexible lease to compute the flexibility value of the lease with continuation, expansion, contraction, and cancelation options.

The above procedure can be manipulated to evaluate other flexible leases that provide different strategic options for the firm to adjust the terms and conditions in the initial lease. The real option approach not only provides a powerful computational approach to price strategic flexibility in leases, but also motivates the flexibility thinking within corporate tenants and facility managers as an appropriate risk handling strategy to cope with the unpredictability of required workspace and uncertainty about the future rental rate in the leasing market. This real option thinking supports identifying and understanding flexibility in leases and provides information for decision makers to decide which flexible terms or conditions are worth incorporating in leases. 


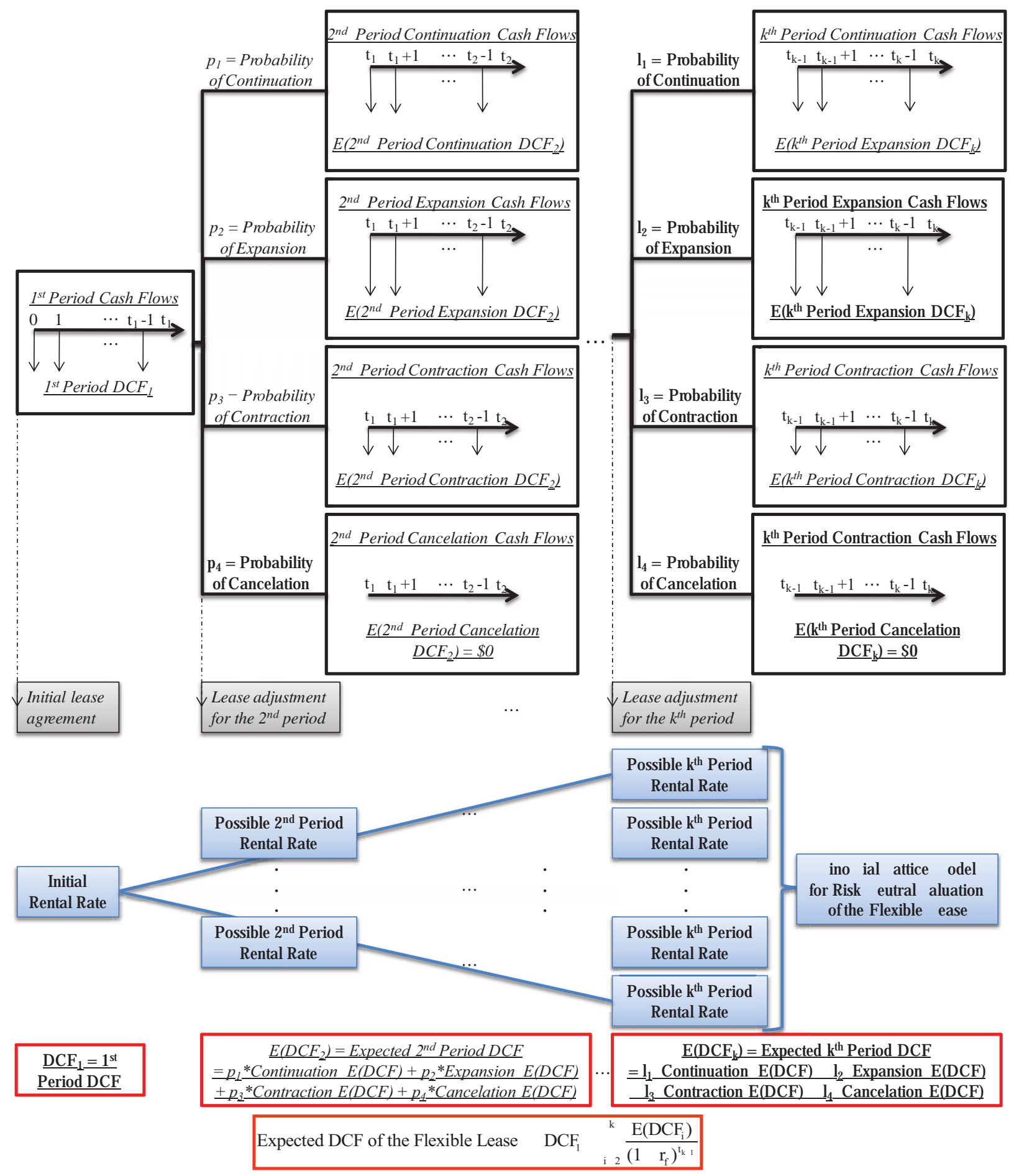

Figure 7. The risk-neutral valuation model to evaluate the expected DCF of a general flexible lease. 


\section{CONCLUSIONS AND FUTURE WORK}

Occupancy costs rank as most firms' secondlargest expense, while corporate real estate costs comprise approximately 5 to $10 \%$ of most companies' expenses (Lyne, 1995). In addition, words like downsizing, restructuring, and right sizing have become well-worn parts of the corporate vernacular (Ashuri and Rouse, 2004; Ashuri and Roper, 2006). Thus, corporate real estate professionals and facility managers are under increasing pressure to quickly meet dynamic workspace needs by spending less corporate wealth. One of the most important strategies for corporate real estate and facility management professionals is to consider the use of innovative, flexible leases. In this paper, a valuation approach is described to compare the financial performance of innovative leases with traditional leases under uncertain characteristics of organizational space demand and the dynamic uncertainty of the leasing market.

Our option valuation model is appropriate for pricing flexibility in leases and is also useful for valuation professionals and commercial developers. The profitability of a commercial development depends on its successful position in the corporate real estate market. The success cannot be achieved without fulfilling prospective tenants' interests in flexible leases. Our option valuation approach helps property valuation professionals assess how flexible leases can provide satisfactory return on investment in dynamic corporate real estate markets.

In addition to the analytical advantages of our real option approach for appropriate pricing of flexible leases, the described option valuation approach supports an innovative way of thinking among the community of real estate professionals and facility managers. The real option thinking helps decision-makers identify and understand strategic flexibility in leasing design and appreciate its significance as an appropriate risk handling strategy to cope with uncertainty related to the firm's required workspace.

The described real option model may be too simple to apply in complex, real-world decisionmaking situations. This research, however, is the first work in a series of research efforts to understand the significance of innovative workspace strategies in corporate real estate and facility management in 21 st century enterprises. The objective is to emphasize on the issues of management flexibility and its role in managing uncertainty in workspace planning. Decision-makers in corporate real estate and facility management are primary beneficiaries of this research. This innovative valuation approach helps them reduce occupancy costs of an organization and manage its corporate real estate assets more efficiently and effectively.

More complicated models should be developed to enhance the application of real option valuation method in practice. As real options models have shown to be conceptually and practically better than other valuation methods for development decision making and land pricing (Brenner et al., 2008), it is important to investigate how these models can be useful in pricing flexible leases in practice. Empirical investigation in corporate leasing markets should be conducted to explore whether and what flexible leasing terms and conditions are incorporated in current industry leases and what pricing techniques are currently used to valuate flexibilities.

\section{REFERENCES}

Amram, M. and Kulatilaka, N. (1999) Real Options: Managing Strategic Investment in an Uncertain World, Harvard Business School Press.

Ashuri, B. (2008) A Real Options Approach to Modeling Investments in Competitive, Dynamic Retail Markets. Georgia Institute of Technology, Atlanta, GA.

Ashuri, B. and Roper, K.O. (2006) Workspace decision-making in the era of transformation. 
Proceedings of 2006 International Conference on Construction \& Real Estate Management, Orlando, FL. October 5-6, 2006.

Ashuri, B. and Rouse, W. B. (2004) Framing strategic trade offs between traditional and virtual enterprises and workplace. Proceedings of International Federation of Automation Control (IFAC) Conference, Atlanta, GA. September 7-9, 2004.

Ashuri, B., Rouse, W. B. and Bodner, D. A. (2008) A real options approach to investment decisions in competitive, dynamic retail markets. 2008 Hawaii International Conference on System Sciences (HICSS-41), Waikoloa, Big Island, HI. January 7-10, 2008, pp. 93-106.

Becker, F. (1999) Beyond alternative officing: Infrastructure on-demand, Journal of Corporate Real Estate, 1(2), pp. 154-166.

Becker, F. and Sims, W. (2000) Managing Uncertainty Integrated Portfolio Strategies for Dynamic Organizations. The International Workplace Studies Program, College of Human Ecology, Cornell University.

Becker, F. and Steele, F. (2000) Alternative Officing Strategies Providing Effective Workspaces. Steelcase Inc. doi:10.1108/14630019910811006

Bengtsson, J. (2001) Manufacturing flexibility and real options: A review, International Journal of Production Economics, 74(1), pp. 213-224. doi:10.1016/S0925-5273(01)00128-1

Black, F. and Scholes, M. (1973) The pricing of options and corporate liabilities, Journal of Political Economy, 81(3), pp. 637-654. doi:10.1086/260062

Bodner, D. A. and Rouse, W. B. (2007) Understanding $R \& D$ value creation with organizational simulation, Systems Engineering, 10(1), pp. 64-82. doi:10.1002/sys.20064

Borison, A. (2005) Real options analysis: Where are the emperor's clothes?, Journal of Applied Corporate Finance, 17(2), pp. 17-31. doi:10.1111/j.1745-6622.2005.00029.x

Brealey, R. and Myers, S. (2003) Principles of Corporate Finance, 7th Edition, McGraw-Hill, New York.

Brenner S., Schulz R. and Härdle W. (2008) Real options and real estate valuation: an implementation study (in German), forthcoming: Zeitschrift für betriebswirtschaftliche Forschung.
Capozza, D. R. and Li, Y. (2002) Optimal land development decisions, Journal of Urban Economics, 51(1), pp. 123-142. doi:10.1006/juec.2001.2240

Chiara, N., Garvin, M. and Vecer, J. (2007) Valuing simple multiple-exercise real options in infrastructure projects, Journal of Infrastructure Systems, 13(2), pp. 97-104. doi:10.1061/(ASCE)1076-0342(2007)13:2(97)

Copeland, T. and Antikarov, V. (2001) Real Options: A Practitioner's Guide, TEXERE, New York.

Davenport, T.H. and Pearlson, K. (1988) Two cheers for the virtual office, Sloan Management Review, 39(4), pp. 51-66.

de Neufville, R., Lee, Y.S. and Scholtes, S. (2008) Flexibility in Hospital Infrastructure Design. IEEE Conference on Infrastructure Systems, Rotterdam, November 8-10, 2008.

Dixit, A. and Pindyck, R. (1994) Investment under Uncertainty, Princeton University Press, Princeton, NJ.

Ford, D.N., Lander, D.M. and Voyer, J.J. (2002) A real options approach to valuing strategic flexibility in uncertain construction projects, Construction Management and Economics, 20(4), pp. 343-351. doi:10.1080/01446190210125572

French, N., Evans, M. and Atherton, E. (2000) Behaviour: flexibility: pricing the uncertainty (an analysis of the pricing of leases with flexible lease terms). In: The 2000 RICS Cutting Edge Conference, London, UK. September 6-8, 2000.

Geltner, D. (1989) On the use of the financial option price model to value and explain vacant urban land, AREUEA Journal, 17(2), pp. 142-158.

Geltner, D., Riddiough, T.J. and Stojanovic, S. (1996) Insights on the effect of land use choice: The perpetual option on the best of two underlying assets, Journal of Urban Economics, 39, pp. 20-50. doi:10.1006/juec.1996.0002

Greden, L. and Glicksman, L. (2005) A real options model for valuing flexible space, Journal of Corporate Real Estate, 7(1), pp. 34-48. doi:10.1108/14630010510812486

Greden, L.V., Glicksman, L.R. and Lopez-Betanzos, G. (2006) A real options methodology for evaluating risk and opportunity of natural ventilation, Journal of Solar Energy Engineering, 128(2), pp. 204-212. doi:10.1115/1.2188959 
Grenadier, S.R. (1995) Valuing lease contracts a real-options approach, Journal of Financial Economics, 38(3), pp. 297-331. doi:10.1016/0304-405X(94)00820-Q

Hull, J.C. (2008) Options, Futures, and Other Derivatives, 7th Edition, Prentice Hall Series in Finance, Upper Saddle River, New Jersey.

Hutchison, N. and Schulz, R. (2007) A real options approach to development land valuation. RICS Research FiBRE September, London.

IFMA (1995) Alternative Officing Research and Workplace Strategies. Haworth Inc. in Collaboration with the International Facility Management Association (IFMA) Foundation, Houston, TX.

Leung, B. Y. P. and Hui, E. C. M. (2000) Real options pricing for property development, International Journal of Strategic Property Management, 4(1), pp. 5-22.

Leung, B. Y. P. and Hui, E. C. M. (2002) Option pricing for real estate development: Hong Kong Disneyland, Journal of Property Investment \& Finance, 20(6), pp. 473-495. doi:10.1108/14635780210446487

Leung, B. Y. P. and Hui, E. C. M. (2005) Evaluation approach on Public-Private Partnership (PPP) urban redevelopment, International Journal of Strategic Property Management, 9(1), pp. 1-16.

Lizieri, C., Crosby, N., Gibson, V. and Thorpe, D. (1997) Right Space, Right Price?: A Study of the Impact of Changing Business Patterns on the Property Market, Research Report, The Royal Institution of Chartered Surveyors (RICS), London, UK.

Luenberger, D. (1998) Investment Science, Oxford University Press, New York.
Lyne, J. (1995) The info-age workplace: now at a location surrounding you, Site Selection, Document \#4206, August 1995.

Mayer, Z. and Kazakidis, V. (2007) Decision making in flexible mine production system design using real options, Journal of Construction Engineering and Management-ASCE, 133(2), pp. 169180. doi:10.1061/(ASCE)0733-9364(2007)133:2(169)

Mun, J. (2003) Real Options Analysis Course: Business Cases and Software Applications, John Wiley \& Sons, New York.

Myers, S.C. (1977) Determinants of corporate borrowing, Journal of Financial Economics, 5, pp. 147-175. doi:10.1016/0304-405X(77)90015-0

Patel, K. and Paxson, D. (2001) Real urban development options at Canary Wharf. In: Real $O p$ tions: Evaluating corporate investment opportunities in a dynamic world, Financial Times/ Prentice Hall, London, UK, pp. 163-176.

Patel, K., Paxson, D. and Sing, T.F. (2005) A review of the practical uses of real property options. RICS Research paper series, 5:1(April).

Shishko, R., Ebbeler, D.H. and Fox, G. (2004) NASA technology assessment using real options valuation, Systems Engineering, 7(1), pp. 1-13. doi:10.1002/sys.10052

Smit, H. and Trigeorgis, L. (2004) Strategic Investment: Real Options and Games, Princeton University Press.

Titman, S. (1985) Urban land prices under uncertainty, American Economic Review, 75(3), pp. $505-514$.

Trigeorgis, L. (1996) Real Options: managerial flexibility and strategy in resource allocation, The MIT Press, Cambridge, Massachusetts.

\section{SANTRAUKA}

\section{LANKSČIOSIOS NUOMOS KOMERCINIAMS NUOMININKAMS VERTINIMAS, ESANT NETIKRUMUI DE்L REIKIAMO DARBO PLOTO}

\section{Baabak ASHURI}

Pristatomas vertinimo metodas, kaip iš komercinio nuomininko perspektyvos įkainoti lanksčiają nuomą su galimybe didinti arba mažinti plotą ir (arba) atsisakyti nuomos. Šiame modelyje, taikant realių pasirinkimo sandorių vertinimo metoda, nustatoma nuomos lankstumo vertė arba priemoka už galimybę rinktis. Ši priemoka - tai maksimali pinigų suma, kurią nuomininkas pasiruošęs investuoti, idant į nuomos susitarima galètú ittraukti konkretú punktą dèl lankstumo. Mūsų modelyje i nuomos rinkos netikrumą ir i netikrumą dèl įmonei reikiamo darbo ploto atsižvelgiama taikant kompleksinę vertinimo sistemą. 